\title{
Intra-Municipal Units in Urban Political Systems in Poland: Vicious Roundabout of Marginalization or Dead-End Street? ${ }^{1}$
}

Paweł Swianiewicz

\begin{abstract}
Neighbourhood/district councils exist in most big Polish cities. But their position in city politics is very weak, although differences among individual cities may be easily identified. There is also a low citizen interest in neighbourhood councils. The article tests a model to explain the variation among the cities and discusses the negative feedback between the dis-engagement of citizens and the narrow set of functions delegated to neighbourhoods. It asks the question if breaking that negative feedback is possible.
\end{abstract}

Key words: neighbourhood, participation, decentralization, public services

\section{Intra-municipal decentralization - rationale and experiments in European cities}

Reforms including the organization of sub-municipal councils in individual districts of the city have been relatively frequent in several European countries for more than 20 years. For example, in 1980 and 1990, such experiments were described in the United Kingdom (Hambleton and Hogget 1990, Blakeley 2010) and Germany (Franke and Löhr 2001). During the last decade, similar innovations were also studied in Belgium (Van Asche and Dierickx 2007), Spain (Lowndes and Sullivan 2008) and the Netherlands (Denters and Klok 2005). Special attention was paid to Scandinavian cities (Bäck et al. 2000; Bäck et al. 2005), where

1 The paper is based on results of the research project "Neighbourhood councils in management of big cities", funded by a grant from the National Research Council for Academic Research (NCN), grant number 149065. The empirical research within the project included an overview of sub-municipal structures in the largest Polish cities as well as detailed case-study research in 13 neighbourhoods of four cities. This paper refers to the results of the former component of the project. The full report from the project is available in Swianiewicz et al. (2013). 
sub-municipal councils were in some cases responsible for spending over half of the total city budget.

The issue has been less intensively discussed in Central and Eastern Europe, where the focus was more on the revitalization of the basic forms of municipal governments than on various democratic experiments, including those with submunicipal units. However, there is also a limited set of literature discussing submunicipal experiments in post-communist countries, as well. A large part of it concerns sub-municipal units in rural areas (for an international review, see Peteri 2008, on Poland, see Derek and Mielczarek 2008). But there is also an increasing interest in neighbourhood government experiments in post-communist cities (for Slovenia, see, e.g., Bačlija and Haček 2009, for Polish empirical analysis, see, e.g. Matczak 2008, Matyjaszczyk 2011, Piechota 2013).

The character of these units is diversified. In many cases, their councils are elected by local citizens and are self-governments of the lowest, local tier. But it also happens that sub-municipal councils are organized by city councillors, who also become members of the district self-government institutions (as in some British cities - see Burns et al. 1984). In some cases the sub-municipal councils are appointed by city authorities (as in Scandinavia - Bäck et al. 2005).

Most of the reforms are seen as elements of the broader process of attempting to strengthen participatory democracy (Quinn 2012, Daemen and Schaap 2012), although Griggs and Roberts $(2012,185)$ note that in some cities, reforms of neighbourhood operations are increasingly concerned with achieving more effective services, rather than enhancing community engagement and political accountability.

Van Ostaaijen et al. (2012) suggest that intra-municipal decentralization may be seen as a strategy making use of both participatory and representative models of decision-making (146). A similar logic is presented by recommendations of the Council of Europe, which supplement the European Charter of Local Government. One of the recommendations is:
[To] develop, both in the most populated urban centres and in rural areas, a form of neighbourhood democracy ... set up sub- municipal level bodies, where appropriate elected or composed of elected representatives, which could be given advisory and in- formation functions, and possibly delegated executive powers2.

What are the benefits expected as a result of intra-municipal decentralization? Lowndes and Sullivan (2008) mention four major arguments:

1. Civic rationale: envigorating local communities and increasing citizen participation in local governance. This argument is shared by several authors. Daeman

2 The capital city of Warsaw, in which the two-tier structure of government is regulated by a separate national law, is excluded from this analysis. 
and Shaap (2012) see it as the main rationale behind most implemented reforms. A similar logic is also presented by Burns et al. (1984), Denters and Klok (2005) and Berry et al. (1993).

2. Social rationale: facilitating a citizen-focused approach to governance.

3. Political rationale: improvement of local democracy since citizens can access neighbourhood governance more easily. Consequently, leaders at the neighbourhood level are more likely to be responsive to citizens' opinions. Van Asche and Dierickx (2007) add that sub-municipal-councils allow for better use of local knowledge.

4. Economic rationale: more efficient and effective use of available resources, in part due to creative local synergies. This argument refers to effectiveness of service delivery (the logic which may be also found in Burns et al. 1984 and Daemen and Schaap 2012). In this context, Van Asche and Dierickx (2007) concentrate on economies of scale - services in which an economy of scale is important should be managed on the city level, but those in which direct contact with citizens or small groups is more important could be delegated to the sub-municipal level. A similar argument is raised by Bäck et al. (2005) regarding flexibility in management arrangements, which can be achieved on the lowest territorial level. In their discussions, the economic effect of intra-municipal decentralization is based on two assumptions: (i) in services delegated to neighbourhood councils economies of scale do not play an important role, (ii) a smaller scale allows organizational improvements and a better organization of services to local conditions. Daemen and Shaap (2012) argue that another benefit of decentralisation includes the financial savings resulting from reducing the burden of central municipal organization. Matczak (2008), arguing for sub-municipal decentralization, refers to Tiebout's classic "voting by feet" argument (the same concept is also referred to in Lowndes and Sullivan).

Some territorial discussions of sub-municipal units refer also to the broad academic debate on the optimal size of local government units (see, e.g., Bačlija and Haček 2009). This, in turn, may be related to the fitting of territorial-administrative boundaries to the catchment area of the services which the local government is responsible for. One potential issue is the situation of over-bounded structures, in which the catchment area is more narrow for the administrative unit (Bennett 1980, 1997). In this scenario, the "too large" local government unit may be limited by having too little attention for and too little information about smaller territories under its jurisdiction. Such a situation may occur when services which benefit one city's neighbourhood are managed at a city-wide level. It may happen that politicians and staff from city hall do not place sufficient attention to local demands, especially if the neighbourhood is located far from the centre and is not an affluent, prestigious district. Political consequences of the low satisfaction level of countless residents of the neighbourhood will have marginal meaning for the politicians. Delegating 
some of the functions to the neighbourhood council might minimize the likelihood of such a situation.

Taking into account the theoretical expectations discussed above, most results of the empirical analysis of consequences of intra-municipal decentralization are disappointing. Griggs and Roberts (2012, 206-207) in their study of UK cities come to the conclusion that neighbourhood government structures often generate unmet expectations among stakeholders. Frustration is related to limited authority offered to neighbourhood activists and their very limited influence on key decision-making. In their study of Birmingham, Rotterdam and Bologna Ringeling et al. (2012, 199-200), conclude that

despite the differences [among the cities] there is a tendency of city politicians and bureaucrats to prevent neighbourhood councils from becoming too strong in relation to the central municipal organization ... these councils are strongly self-referential, deliberating about their jurisdictions, their internal organization and their relation with the central city. They certainly don't organize participation of citizens in their neighbourhood ... we may conclude that neighbourhood councils hardly function as a way of diminishing the gap between city government and citizens ... even if they are created as a tool of democratic improvement, the neighbourhood councils often don't act accordingly. Rather, they tend to duplicate the problematic game of local council politics for which they were meant to be a solution.

In a study of Scandinavian cities, Beck et al. (2005) come to a critical assessment of the reforms implemented in that region. Regarding the results related to the active participation of citizens, the results are very limited, in spite of an effort made to create new channels of communication. Contact of neighbourhood councillors with citizens is not much more frequent than citizens' previous contact with city councillors. Beck et al. have not found any durable effects of increased community involvement. The results related to the expected cost savings of service delivery are also ambiguous.

\section{Scope and method of research}

In this paper we analyze the situation of sub-municipal units in the 22 largest Polish cities (all cities above 150,000 residents). ${ }^{3}$ The paper addresses the following questions:

- How often do Polish cities decide to organize sub-municipal councils?

3 Except for the capital city - Warsaw - whose local government structure is regulated by a separate law and is hardly comparable with other Polish cities. 
- What is the role of the sub-municipal councils in the provision of local government functions?

- What is the level of citizens' interest in sub-municipal councils?

- What factors explain the differences between individual cities?

The latter two questions are a special focus of this paper. In the following sections, we present a model explaining the variation of citizen interest in neighbourhood structures and test the theoretical assumptions of the model with empirical data from Polish cities.

Due to low samples Spearman correlation coefficients (rather than Pearson's) are used as measures or simple inter-dependencies among variables.

Most of the data originates from official sources - official cities' web-sites, reports of the National Electoral Bureau, official statistics. But occasionally we also refer to quantitative information collected within the frame of the wider research project, which included in-depth semi-structured interviews and responses to the questionnaire survey of over 35 city-level politicians and bureaucrats, 55 neighbourhood councillors as well as a survey of 1161 citizens of four Polish cities (Kraków, Poznań, Gdynia and Olsztyn). All interviews were conducted between June and October 2012, and access to web-sites was between September and December 2012.

\section{Sub-municipal councils in Polish cities - institutional setting}

Polish Law on Local Government delegates the discretion to create sub-municipal district (neighbourhood) councils to the city level. The law defines only a very general framework for neighbourhood councils' operation, but decisions on the boundaries of sub-municipal units, as well as details of the electoral system, allocation of financial resources, and responsibilities are in the hands of the city council. The law allows the use of different names for sub-municipal units, usually districts (dzielnice) or neighbourhoods (osiedla), although cities sporadically use their own original terms. However, the law does not differ concerning competencies and institutional structures of dzielnica or osiedle, and in practice, the difference between the two is fuzzy. In this paper we use the term "neighbourhood" for any type of sub-municipal structure.

According to 2012 data, sub-municipal councils have been organized in 19 out of the 22 largest cities. In one of the remaining 3 cities - Białystok - neighbourhood government structures existed between 1995 and 2006, until they were abolished by a decision of the city council and the mayor. In the two remaining cities (Kielce and Radom), sub-municipal councils were never organized. 
In 12 cities, the neighbourhood councils cover the whole territory of the cities, while in the remaining 10, sub-municipal structures operate in only some of the neighbourhoods (usually in those in which the bottom-up initiative was the most lively).

Figure 1 illustrates the territorial division of Polish cities into sub-municipal units, showing the average population of the neighbourhood unit. The measure is a simplification, since there are considerable variations in unit size within one city. In the extreme cases of Łódź and Wrocław, the ratio of the largest to the least populated sub-municipal unit is 70:1.

\section{Figure 1}

Average population size of neighbourhood unit in Polish cities (1,000s of residents)

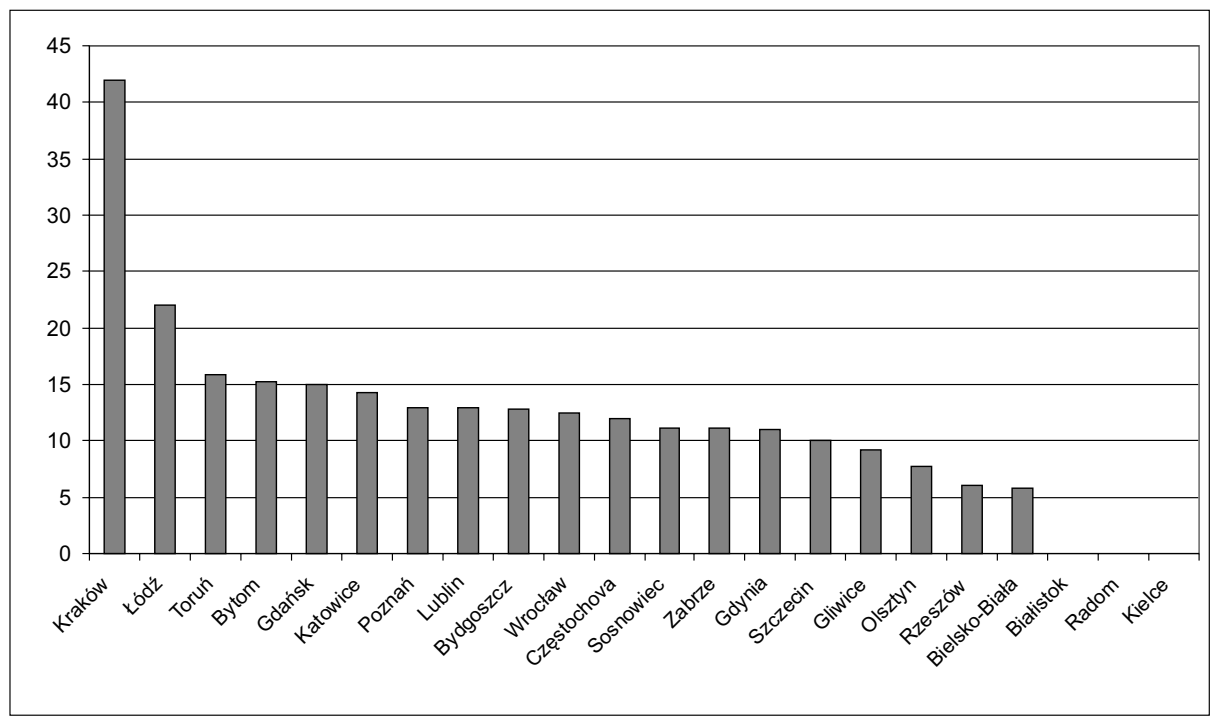

Source: websites of analyzed cities.

The one city with a territorial organization which is different than in any other Polish city is Kraków, with sub-municipal units inhabited on average by more than 40,000 residents. A similar structure was recently suggested by the mayor of Poznań, but his proposal was rejected by the city council. The second largest neighbourhoods might be found in Łódź, but they are more than two times smaller than the sub-municipal units of Kraków. On the other extreme, there are the cities of Bielsko Biała and Rzeszów, in which the average neighbourhood has just over 5,000 residents. As a rule, the larger units are found in larger cities; the correlation between city size and average neighbourhood size is +0.68 (coefficient calculated on the basis of data for 19 cities). 


\section{The role of neighbourhood councils in city politics and in the provision of urban services}

Regardless of the differences between cities, the role of neighbourhoods in the politics of Polish cities is rather marginal. This conclusion is drawn from two observations regarding

(1) the presence of neighbourhoods in strategic planning documents developed in the cities,

(2) the amount of financial resources transferred to the neighbourhood councils.

Reading urban development strategies, we observe that neighbourhoods are mentioned only in one third of the cities analyzed. ${ }^{4}$ The case of Białystok, where neighbourhood councils were abolished in 2006, is especially intriguing. The Białystok City Development Strategy (adopted in 2010, i.e. four years after the abolition of neighbourhood councils) states that one of the policies of the city would support and promote active participation of local communities and operation of neighbourhood councils. In the same document we may read that: in case of the will expressed by the local community, city hall will organize elections to neighbourhood councils. This declaration has little to do with the actual behaviour of the city government, which has refused a couple of bottom-up initiatives to re-establish sub-municipal structures in the last few years.

The development-strategy documents usually reflect only a marginal role (if any) attached to the existence of sub-municipal structures. The role of sub-municipal councils in the strategic documents seems not to be larger than that of local societal organizations and other bottom-up social initiatives and are referred to in a similar way (e.g. Poznań, Bydgoszcz, Gdynia, Toruń and Olsztyn). Moreover, the role of the neighbourhood councils is often described as more marginal. The strategy documents often refer to districts or neighbourhoods as parts of the territory, but those references do not mention their self-government character (e.g. Gdynia). Sub-municipal councils are not depicted as important partners for city government, even in the formulation of policies concerning individual parts of the city. The only roles which are sometimes assigned to neighbourhoods are as the animator of local communities and as rather insignificant consultants on city-territorial policies (e.g. Częstochowa, where they are mentioned as an element of public consultation procedures for city development programmes).

The low profile of neighbourhood councils is also evident by the amount of financial resources assigned to them (expressed as a proportion of total city-budget expenditures - see Figure 2). Our data take into account not only resources which are directly allocated to sub-municipal units, but also other expenditures, which

4 Sub-municipal councils are mentioned in strategies of Białystok, Bydgoszcz, Częstochowa, Gdynia, Kraków, Olsztyn, Poznań and Toruń. 
are shaped by neighbourhood councils' priorities. Also included are operationally related costs, such as the rental of office space for sub-municipal councils.

Figure 2

Sub-municipal spending as percentage of total city budget expenditures

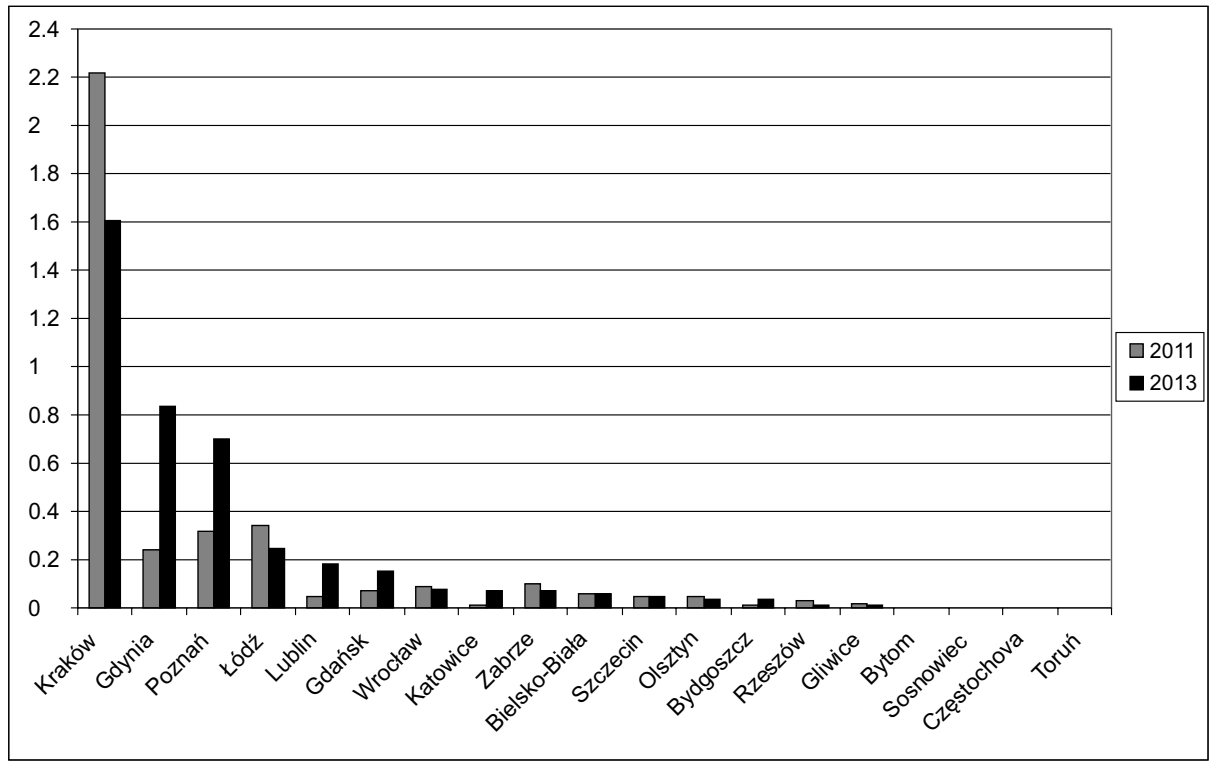

Source: city budgets accessed through web-sites of analyzed cities. In the case of 2013 the approved budget plans are taken into account.

Considering the negligible proportion of sub-municipal spending in city budgets, it is difficult to expect sub-municipal units to play a crucial role in the provision of urban services. Sub-municipal spending (Figure 2) is also very low in comparison to sub-municipal spending in cities of other European countries. In several Scandinavian cities, sub-municipal units have been spending close to half of the city budgets (Bäck et al. 2005). In Poland the only city in which the concept of such radical intra-city decentralization was considered is Poznań, but the mayor's proposal was rejected by the city council.

Nevertheless, the variation among cities is very significant. Once again, Kraków is an exceptional case, since it is the only Polish city in which sub-municipal councils may spend more than $1 \%$ of the city budget (in 2011 it was more than $2 \%$ ). The second group is Gdynia and Poznan, in which neighbourhood councils have discretion over more than $0.5 \%$ of the city budget, and this proportion has been on an upward slope over the last few years. The third group are cities with proportionally very small sub-municipal budgets $(0.05-0.5 \%)$, which includes Łódź, Lublin, Gdańsk, Wrocław, Katowice, Zabrze and Bielsko-Biała. In the remaining 
cities, the size of sub-municipal budgets is almost invisible (less than $0.05 \%$ of city expenditures. In four cities it is even below $0.01 \%$ ).

Fiscal austerity measures adopted by several cities in recent years as a response to the economic crisis resulted in further cuts to sub-municipal budgets in some cities (of which Kraków ${ }^{5}$ and Olsztyn are good examples). In some other cities, regardless of the fiscal pressure, the proportion and the absolute volume of funds spent by neighbourhood councils have been gradually increasing. Gdynia and Poznań are perhaps the most characteristic in this respect. In both cities the decisions to increase the allocation for sub-municipal units' investments were made a few years ago and have been implemented. Gdańsk and Lublin provide less dramatic but also clear examples of a similar trend.

\section{Neighbourhood councils and their roots in local communities - turn-out in sub-municipal elections}

As is clear from strategic documents developed by city governments, the main role of sub-municipal councils is activation and representation (e.g. in consultations on decisions concerning the neighbourhood) of local communities. In such circumstances, to understand how well this role may be performed, it is crucial to check how citizens perceive neighbourhood councils. In this paper we focus on one simple indicator of citizen interest - participation in sub-municipal elections. ${ }^{6}$ International comparative data analyzed by Denters and Klok (2013) suggest that turn-out in Polish sub-municipal elections is among the lowest in Europe.

Before we present the detailed data and their interpretation it is useful to present more general observations concerning the electoral system. It is very important to mention that in Poland, elections to city and regional councils do not occur on the same day as voting for sub-municipal governments. ${ }^{7}$ This certainly has a (negative) influence on voter turn-out. Sub-municipal elections are seen as less important, and voting requires a conscious decision.

5 Which is contrary to the plans formulated in the second half of 1990, when a spending increase to $5 \%$ of the city budget was projected ("Rozmowa z...", 2006). In reality - as is shown in Figure 2 - the actual share in 2013 dropped below $2 \%$. This development was influenced by the almost hostile relationship between the current city mayor (elected for the first time in 2002) and the Kraków district councils. The nature of this relationship has been an area of our analysis in case study research in Kraków (Swianiewicz et al. 2013), but it is beyond the scope of this paper.

6 More extensive analysis of the relationship between local communities and sub-municipal councils may be found in Swianiewicz et al. (2013).

7 The only exception to this rule is city of Łodź. Even in that case, the sub-municipal elections do not occur in the same room, so typically, after voting for city council and city mayor, citizens have to go to the upper floor (or a separate room) to cast a vote for the neighbourhood council. A similar system was in place in Kraków before 2010, but recent elections for city district governments were organized on a different day. 
In practice, there are two different systems of voting for sub-municipal councils in Poland. The first type is arranged in the same way as parliamentary or city elections - i.e. voters can come at any time of the day to cast their vote for the nominated positions. But in some cities, voting is organized during general meetings (assemblies) of citizens of the neighbourhood.

The data in Figure 3 show that turn-out in Polish sub-municipal elections is usually low. It is also meaningful that information on voter turn-out is not easy to be found on city websites. In several cases, obtaining relevant information at city hall is not easy, either. Eventually, we managed to collect information from 17 out of 19 cities. Especially in cities in which elections are organized during general assemblies of citizens, information on turn-out is not systematically collected, so it is hard to access. This poverty of information is one more indirect indication of the marginal role played by sub-municipal units in city politics.

Kraków and Łódź are the only cities in which turn-out in recent elections was higher than $10 \%$. Łódź had the highest score, but as mentioned above, it is the only city in which sub-municipal and municipal elections took place on the same day. In the next four cities (Gdynia, Gdańsk, Pozanń and Lublin) the average turn-out was over $5 \%$. In others it was lower, sometimes even below $1 \%{ }^{8}$

Having in mind the limited interest of voters, some cities are trying to limit the existence of sub-municipal councils by setting up thresholds for turn-out, below which the appointment of the council would not be possible. However, neighbourhood activists are often very successful at lobbying for lowering or abolishing the threshold. The highest threshold (20\%) was adopted in the 1990s in Zabrze, but it was gradually decreased and finally abolished over the last dozen years. In Gdańsk, the threshold was lowered from $10 \%$ to $8 \%$ and then to $5 \%$ over the last decade. In a few cities, in which elections occur during general assemblies of neighbourhood citizens, the threshold is defined as an absolute number, not as a proportion of eligible voters. This number is usually quite low (for example, meeting attendance of 60 or 100), and sometimes it is additionally reduced for a "second chance" assembly of citizens. Nevertheless, there are cases in which even such an unambitious threshold cannot be achieved, and the council cannot be elected due to a lack of popular interest. For example, in Rzeszów the threshold is defined as 100 citizens and lowered to 60 citizens during the "second chance" assembly meeting. Taking into account neighbourhood population size, the threshold translates to ca. $1 \%$ of eligible voters.

8 It should be mentioned however, that in cities in which sub-municipal councils operate on only part of the city territory, we calculated average turn-out by dividing the number of actual active voters by the total number of eligible voters in the whole city. The justification of this method is the fact that sub-municipal councils are usually not created (so elections do not occur) in those parts of the city in which bottom-up interest in the creation of the neighbourhood government structures was the lowest. An alternative method of taking into account the average from only a few of the most active neighbourhoods (in which elections took place) would result in an overestimation of citizen interest in sub-municipal councils. 
Nevertheless, in Rzeszów's recent election the turn-out for the assembly meeting permitted the election of only 25 out of 29 sub-municipal councils.

\section{Figure 3}

Average turn-out in recent sub-municipal elections (2009-2012)

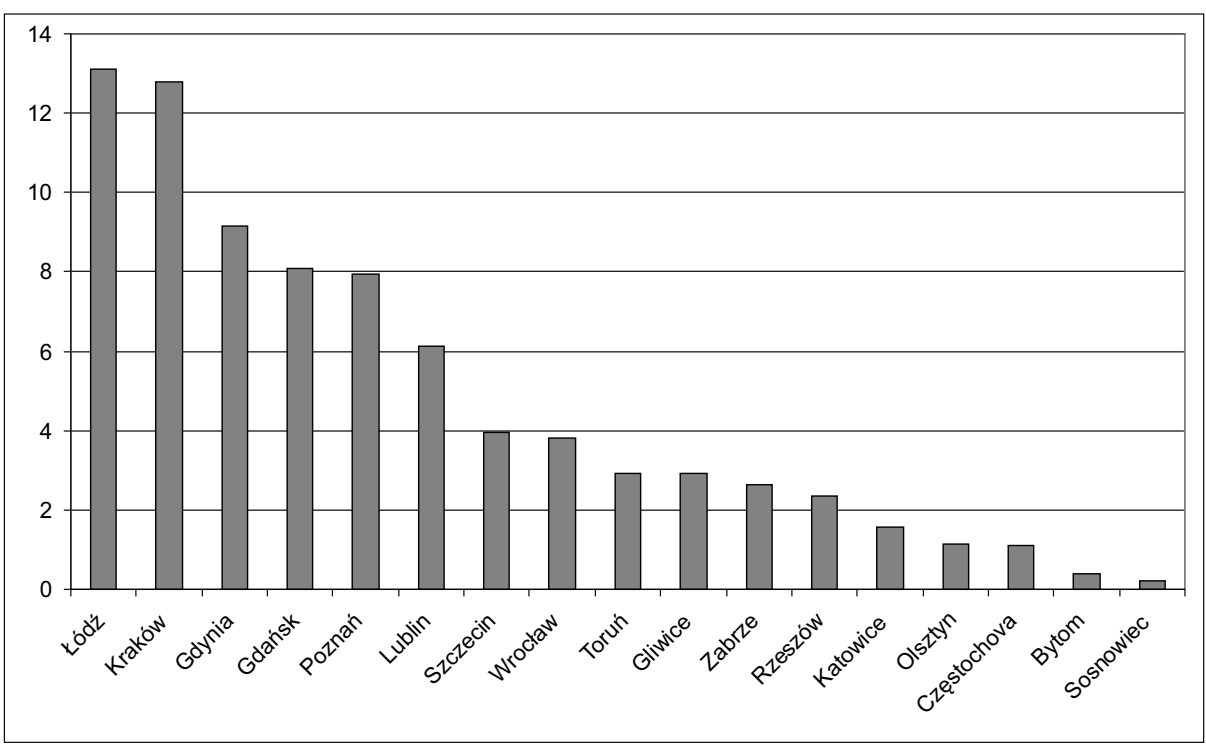

Notes:

1. turn-out calculated as the number of voters, divided by the number of eligible voters in the city. The same formula was applied to cities where sub-municipal councils operate in only part of the city.

2. elections to the Łódź sub-municipal councils were organized on the same day as city mayor and city council elections.

Source: web-sites of analyzed cities and data of National Bureau of Election 


\section{Figure 4}

Proportion of neighbourhoods in which turn-out in sub-municipal elections was higher than $10 \%$ of eligible voters

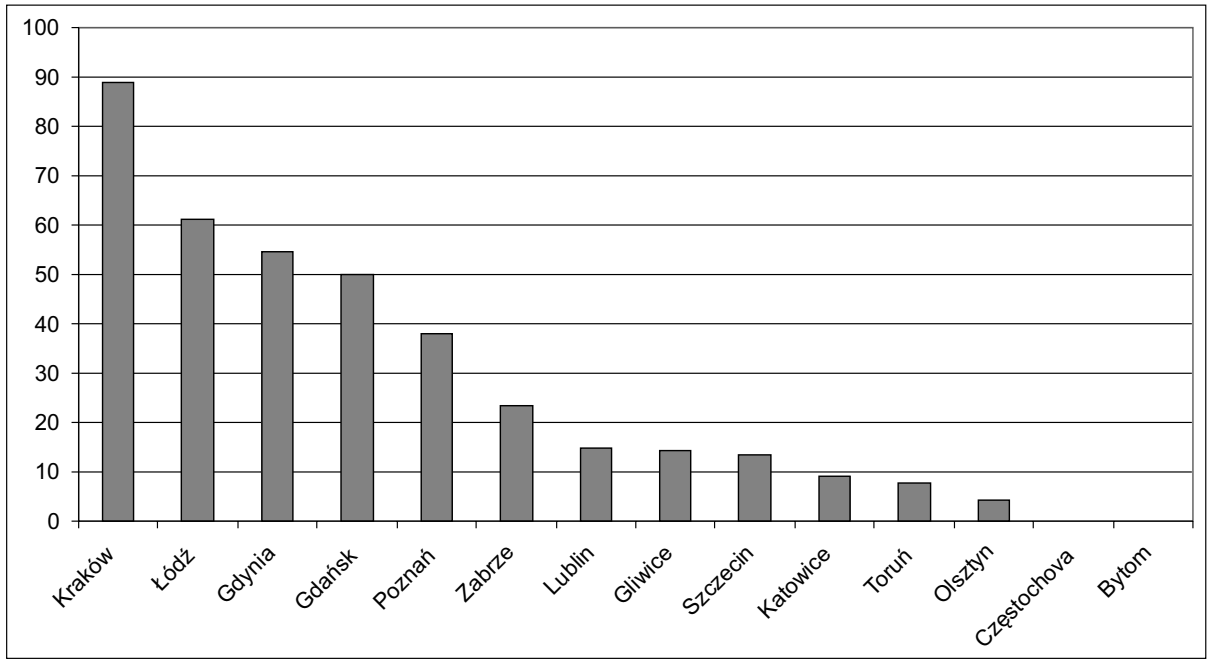

Source: web-sites of analyzed cities and data of National Bureau of Election

\section{Explaining turn-out and its role in service delivery: Vicious roundabout of marginalization?}

The position of sub-municipal councils, as presented in the previous sections, is in most cases very weak, nevertheless, there are differences between individual cities. Therefore, we may ask what factors might influence the pattern of these differences, both on the city level and on the level of individual neighbourhoods. In our explanatory model we will use two dependent variables to illustrate the position of neighbourhood governments in city politics:

- The share of city-budget spending in the 2013 budget plan (which illustrates the role in providing functions guaranteed by the cities);

- Turn-out in recent sub-municipal elections (which illustrates citizen interest in sub-municipal structures).

Bäck et al. $(2005,63)$ formulated three variables in their study which might influence citizen interest in sub-municipal government structures:

- Relevance - the broader the range of services allocated to the sub-municipal units, the more people will probably devote their energies to influencing submunicipal politics. This variable refers also to the earlier concept of explaining citizens' interest in politics, which was developed by Dahl and Tufte (1973). 
- Accessibility - expected citizen involvement is smaller in huge sub-municipal units, which may be seen by voters as less accessible and less inviting for participation.

- Localism - citizen interest might be increased by the perception of sub-municipal councils as at least partially autonomous. In particular, the method of electing/nominating sub-municipal council members seems to be important.

The variable of localism is not interesting for our study, since there are no differences among Polish cities in this respect. But relevance and accessibility are operationalized by the share of budget-spending ${ }^{9}$ and neighbourhood population size and are tested below. Additional independent variables of the model include:

- City population size - we assume in our analysis that demand for sub-municipal structures is higher in the largest cities, which are more internally diversified, so the need to express the territorial interests of individual neighbourhoods may be perceived as more important. This variable may be treated as another version of the relevance argument explained above.

- Human capital, measured by the proportion of the population with university degrees. As in the classic structural model of electoral behaviour (e.g. Lipset 1981), it is assumed that people with higher social status (expressed in particular by their education level) would be more inclined to be politically active. Unfortunately, we do not have access to data on the education level at the neighbourhood level, so this variable may only be used for analysis of variation among cities.

- Social capital and development of civic society institutions:

- Levels of civic involvement, measured by turn-out in recent local government (city-level) elections.

- Levels of trust between neighbours and friends. ${ }^{10}$

- Density of voluntary social organizations (per 1,000 population, 2008 data).

These variables refer to theoretical concepts linking social capital and development of civic-society institutions with political engagement on the local level (e.g. Putnam et al. 1993).

- Local embeddedness of the population, measured by the proportion of population born in the same city. We assume that people with stronger local roots will be more inclined to be interested in local political issues. This specific variable

9 In this part of analysis the budget spending of neighbourhood councils plays a role of independent variable of the model.

10 Data from the survey conducted on a random sample of Polish citizens in September-November 2007 (survey conducted by CBOS, by the team LED by prof. Krzysztof Zagórski, N=38866). The sample in 23 cities included in our research: $N=16588$ (in seven of our cities the sample was over 1000, in the next seven it was between 500 and 1000). 
may be to a large extent identified with another form of the social-capital factor, which is discussed in the previous item.

We expect that these independent variables may influence not only citizens' interest, but also the role of sub-municipal units in service delivery and in local politics in general, since the high value of human and social capital will result in higher demand for intra-municipal decentralization.

However, our empirical data do not confirm that the above independent variables are powerful enough to explain the variation of the share of sub-municipal spending in city-budget expenditures. Very weak correlations are between the level of sub-municipal budgets and the education level of citizens (Spearman coefficient +0.34 , insignificant on 0.05 level, all correlations are also presented in Table 2), as well as between the level of spending and the density of social organizational networks ( +0.31 , also insignificant on 0.05 level). We have not found any relevance of other measures of social capital in explaining the size of neighbourhood budgets.

The size of sub-municipal budgets is correlated with the size of the city (Spearman coefficient +0.56 , significant on 0.01 level), however this result is biased by the extreme value of the dependent variable for Kraków, which is the largest city in our sample. If Kraków is excluded from the analysis, the correlation coefficient drops to 0.48 (insignificant on 0.01 level, but still significant on 0.05 level). If we take into account 2013 budget data, the correlation between the mean size of sub-municipal units and their share in the city budget is insignificant (Spearman coefficient 0.303 , insignificant on 0.05 level). Such a relationship would be a confirmation of a general tendency often identified in the analysis of decentralization on the municipal level (Page and Goldsmith 1987, Bours 1993, Swianiewicz 2010b), but it does not seem to work for analysis of the sub-municipal level. Local embeddedness (percentage of citizens born in the same city) shows no correlation with intra-municipal financial decentralization, either.

These results of our analysis suggest that the level of sub-municipal decentralization depends on other factors not included in our model. Information collected in in-depth case studies suggests that the attitude of the city leader (the mayor) is of crucial importance (Swianiewicz et al. 2013).

There is also a very weak relationship between sub-municipal decentralization (measured by the proportion of the budget allocated for neighbourhood councils) and the level of citizens' trust in local governments. This indirectly suggests that the issue of neighbourhood councils is not an important topic for most local communities.

Stronger relationships are identified between citizen interest in neighbourhood-council elections and the level of sub-municipal decentralization. There are regularities which confirm the significance of our explanatory model. First, turnout is usually higher in big cities (Spearman coefficient 0.743 , significant on 0.01 
level, see also Figure 5), in which "demand" for articulating and representing distinct territorial interests of individual parts of the city is larger. In big cities, submunicipal units are more required and citizens note this necessity.

Second, higher turn-out usually occurs in cities where neighbourhood councils have more responsibilities (measured by the size of their budgets - see Figure. 6 ). The Spearman correlation is +0.804 , significant on 0.001 level). This relationship follows Dahl and Tufte's (1973) expectation that the wider scope of functions of local authorities tends to increase citizen interest in council operation.

However, Dahl and Tufte presented their expectation in a different context that of the discussion of the optimal size of local government jurisdictions. They argued that larger local governments may be responsible for a wider scope of functions, so territorial consolidation may bring more social involvement in local politics. This logic has not found universal confirmation, since local turn-out is often higher in small jurisdictions (and this regularity certainly applies to Polish municipal elections ${ }^{11}$ ). Denters (2002) explains the relationship between city size and turnout in local elections both referring to rational choice (in a small group, a single vote carries more weight) and to trust in politicians: social trust is based on strong personal ties in small communities. Decline of community and social trust resulting from increasing scale will be reflected in declining political trust.

This logic presented by Denters finds confirmation in the intra-municipal variation in turn-out in neighbourhood council elections. As is shown in Table 1, in all Polish cities for which relevant data are available on the neigbourhood level, there is a negative correlation between neighbourhood population and voter turnout in sub-municipal elections. If we take into account the Spearman coefficient, they are statistically significant in all cities except for Łódź.

11 In international comparative data, the rule was confirmed, e.g., by Keating 1995, Denters 2002, Rose 2002 and Houlberg 2010. For Polish data, see, e.g., Swianiewicz and Herbst 2002, Swianiewicz 2010a. 


\section{Figure 5}

City size and turn-out in sub-municipal elections

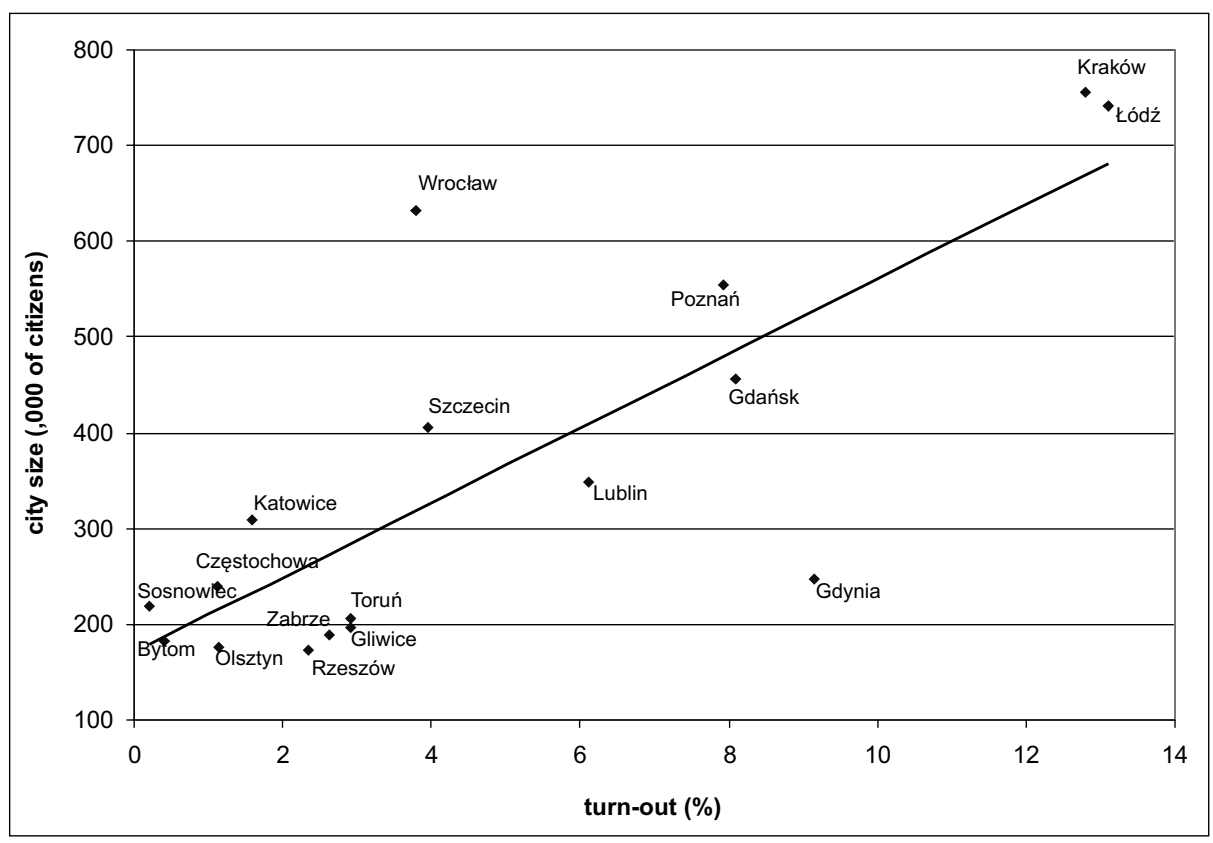

Source: own calculations based on official statistics. 


\section{Figure 6}

Turn-out in sub-municipal elections and size of sub-municipal budgets in 2013

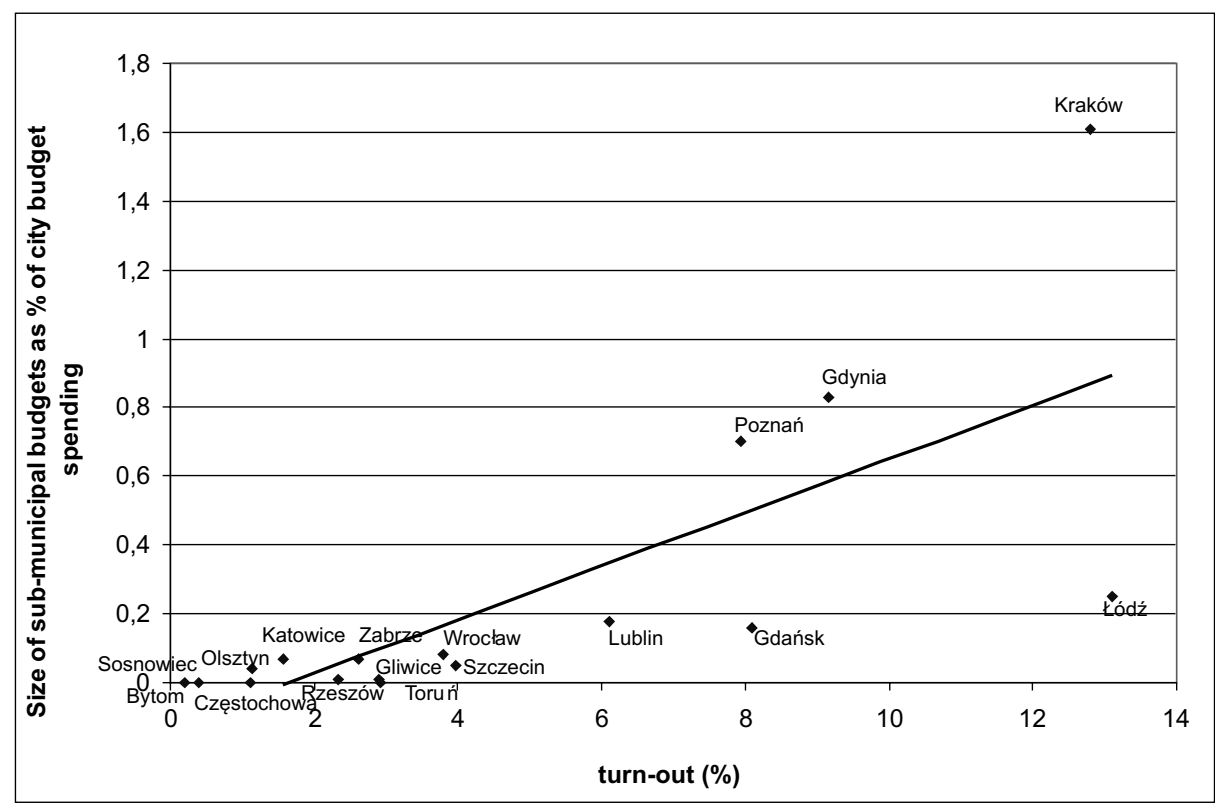

Source: own calculations based on official statistics

Table 1

Spearman correlation coefficients between neighbourhood population and voter turn-out in recent sub-municipal elections

\begin{tabular}{|l|c|c|c|}
\hline & R & Significance & N \\
\hline Zabrze & -0.89 & 0.000 & 17 \\
\hline Olsztyn & -0.85 & 0.000 & 23 \\
\hline Toruń & -0.85 & 0.000 & 13 \\
\hline Szczecin & -0.75 & 0.000 & 37 \\
\hline Gdynia & -0.71 & 0.000 & 22 \\
\hline Lublin & -0.68 & 0.000 & 27 \\
\hline Gdańsk & -0.63 & 0.000 & 27 \\
\hline Poznań & -0.59 & 0.000 & 42 \\
\hline Kraków & -0.74 & 0.001 & 18 \\
\hline Częstochowa & -0.62 & 0.003 & 20 \\
\hline Gliwice & -0.63 & 0.050 & 10 \\
\hline Łódź & -0.27 & 0.273 & 24 \\
\hline
\end{tabular}

Source: own calculations based on data from official web-sites of the cities 
The conducted analysis allows it to detect differences not only among neighbourhoods of various sizes but also among different locations and types of units: suburban (located far from the centre and comprising single-flat houses), sub-municipal units in city centres and multi-flat big housing estates.

The highest levels of interest in sub-municipal governments are observed in small and suburban neighbourhoods. The lowest turn-out is observed in big submunicipal units in the city centres, as well as in big multi-flat housing estates. The analysis of the extreme values of turn-out shows that the same relationship may be found in all 12 cities for which we found precise turn-out data for each neighbourhood council. The highest turn-out was found for the very small (up to 2,000 population) suburban single-flat-housing neighbourhoods of Morasko-Radojewo (Poznań, 32\%) and Dolina Łódki (Łódź, 25\%). The lowest turn-out was found in big (over 20,000 population) multi-apartment-housing estates: Jaroty (Olsztyn, $0.3 \%$ ), Północ (Częstochowa, $0.4 \%$ ) and Ołpin (Wrocław, 0.5\%).

The relationship between size and type of neighbourhood and citizen interest in sub-municipal institutional structure was not only observed in voter-turn-out data. In a recent analysis of 13 neighbourhoods of four Polish cities (Swianiewicz et al. 2013), it was also noted that the general levels of citizens' knowledge of submunicipal governments ${ }^{12}$, as well as the level of trust in sub-municipal councillors (compared to the trust in city councillors), are higher in small neighbourhoods, located on the peripheries of large cities (see Figures 7 and 8). Citizens' trust in neighbourhood councillors is higher than trust in members of city assemblies in 11 out of the 13 neighbourhoods studied (the exceptions were the most centrally located units: The Old City in Kraków and The Old City in Poznań). But the difference between trust in neighbourhood and city councillors is much larger in small sub-municipal units and in neighbourhoods of a suburban character than in the large, centrally located neighbourhoods.

12 Measured here by an index composed on the basis of answers to several questions, related to citizens' awareness of the existence of sub-municipal governments, knowledge of the names of neighbourhood councillors etc. 


\section{Figure 7}

Index of knowledge and level of trust in neighbourhood councillors depending on neighbourhood type and location

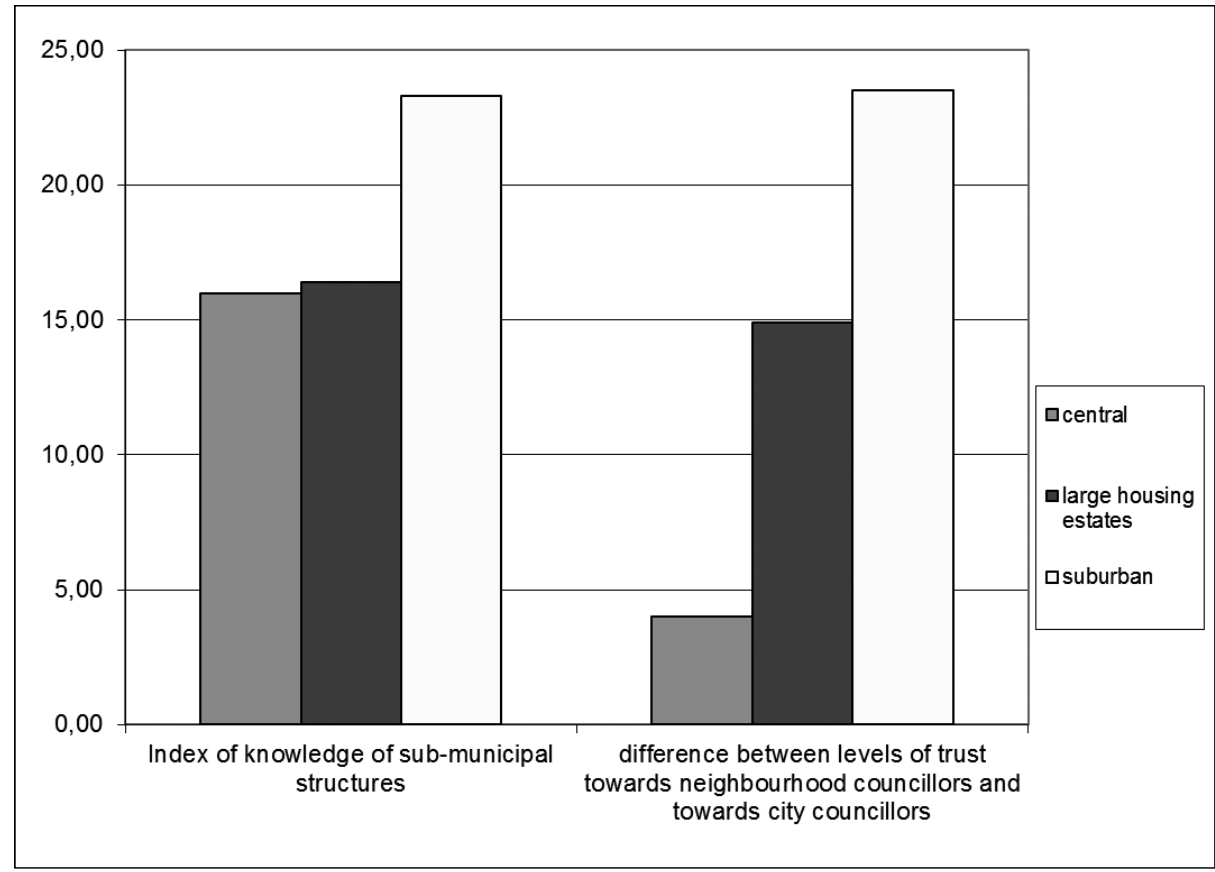

Note: The rightmost bars in the figure refer to the differing levels of citizens' trust in neighbourhood and city councillors. Positive values signify higher trust in neighbourhood councilors, negative values higher trust in city councilors.

Source: own calculation on the basis of a survey of citizens in 4 cities $(\mathrm{N}=1161)$ 


\section{Figure 8}

Index of citizen knowledge and level of trust in neighbourhood councillors according to neighbourhood population

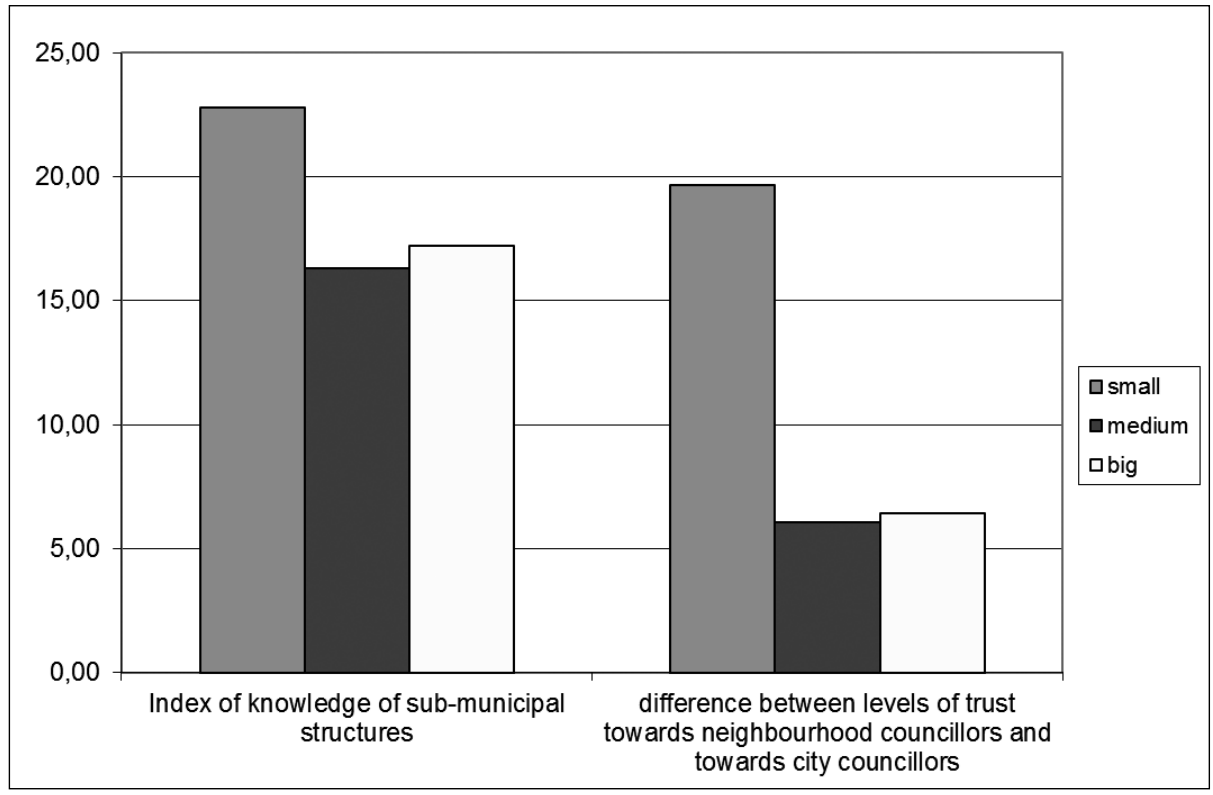

Note: The rightmost bars in the figure refer to the differing levels of citizens' trust in neighbourhood and city councillors. Positive values signify higher trust in neighbourhood councilors, negative values higher trust in city councilors.

Small neighbourhood means populations below 8,000, medium 8-20,000 residents, and large population over 20,000 .

Source: own calculation on the basis of survey of citizens in 4 cities $(\mathrm{N}=1161)$ 


\section{Figure 9}

Factors explaining variation in the importance of sub-municipal councils - results of empirical analysis

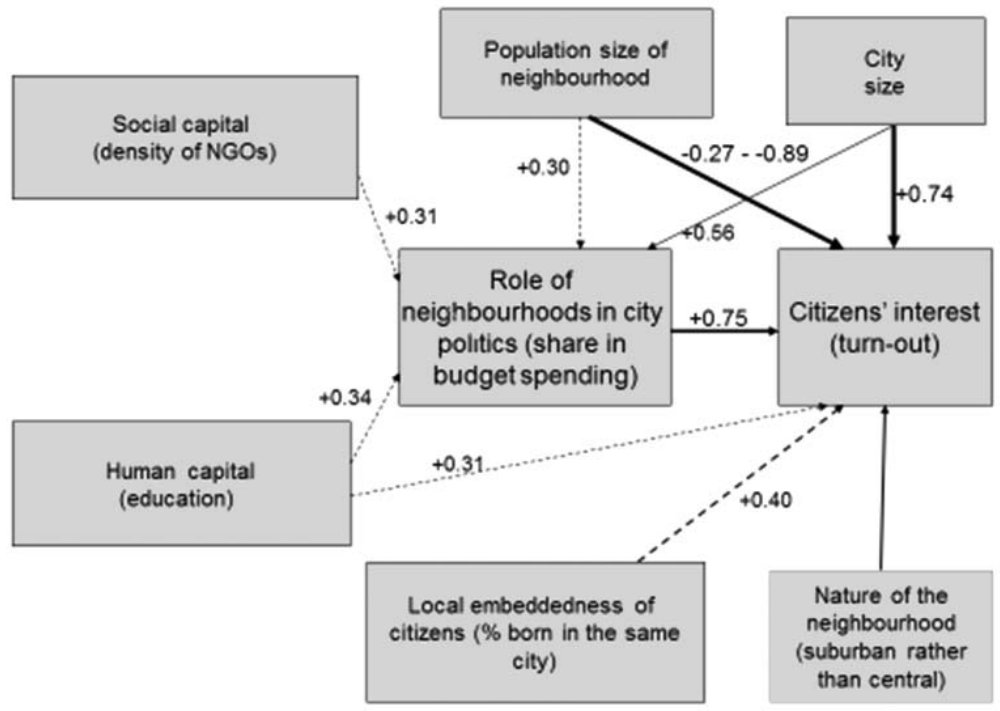

Additionally, we found that there is a weak relationship between turn-out in neighbourhood elections and local embeddedness of the population (correlation +0.40 ); however, this relationship is not statistically significant on 0.05 level. Also, apparently there is a weak influence of the human capital, measured by education level (correlation +0.31 , also insiginificant on 0.05 level). Once again, the impact of the density of local, voluntary social organizations (as well as other measures of social capital) proved to be unimportant. It is clear that this form of social activity does not affect the functioning of sub-municipal councils. Neighbourhood councils are, to a very limited extent, channels of civic involvement. In some interviews during the case study research we were told that voluntary social organizations are sometimes perceived (by both sides) as competitive rather than synergistic support for sub-municipal councils. The graphic summary of found relationships is presented in Figure 9, and values of Spearman correlation coefficients are in Table 2. 


\section{Table 2}

Spearman correlation coefficients between size of sub-municipal budgets, turn-out in sub-municipal elections and potential explanatory variables used in the models

\begin{tabular}{|l|c|c|}
\hline \multicolumn{1}{|c|}{ Independent variable } & $\begin{array}{c}\text { Turn-out in } \\
\text { sub-municipal } \\
\text { elections }\end{array}$ & $\begin{array}{c}\text { Share of the city budget } \\
\text { deconcentrated to sub- } \\
\text { municipal councils }\end{array}$ \\
\hline City population size & $0.78^{* *}$ & $0.56^{* *}$ \\
\hline Population size of neighbourhoods & $0.27-0.89(1)$ & 0.30 \\
\hline $\begin{array}{l}\text { Education - percentage of adult } \\
\text { population with university degree }\end{array}$ & 0.31 & 0.34 \\
\hline Turn-out in 2010 municipal election & 0.11 & -0.06 \\
\hline $\begin{array}{l}\text { Density of NGOs (per 1,000 } \\
\text { population) }\end{array}$ & 0.31 & 0.31 \\
\hline $\begin{array}{l}\text { Embeddedness - proportion of } \\
\text { population born in the same city }\end{array}$ & 0.40 & -0.04 \\
\hline $\begin{array}{l}\text { Share of the city budget } \\
\text { deconcentrated to sub-municipal } \\
\text { councils }\end{array}$ & $0.88^{* *}$ & - \\
\hline
\end{tabular}

(1) city level correlations. Various results for various cities.

* correlation significant on 0.05 level

** correlation significant on 0.01 level.

\section{Conclusions}

Sub-municipal government structures are very popular among large Polish cities. They operate in 20 out of 23 cities with a population over 150,000. However, the function of sub-municipal units in the largest Polish cities is very marginal in most cases, which is perhaps best illustrated by the negligible share of city expenditures spent at the neighbourhood level. At the same time neighbourhood councils are often poorly rooted in local communities - citizens' interest in their operation is very limited, which may be illustrated by very low voters turn-out but also by the low level of knowledge of neighbourhood activists or the limited level of trust in them. However, there are significant differences among individual cities. Our model was to a limited extent successful in explaining variation of the level of sub-municipal decentralization. But we have been more successful in explaining the varying level of citizens' interest. The main conclusions can be summarized in the following items: (i) there seems to be higher citizen demand for neighbourhood structures in the largest cities and lower demand in smaller cities; (ii) the stronger role of sub-municipal structures in the provision of city functions results in larger citizen interest in neighbourhoodlevel institutions; (iii) there are also differences on the neighbourhood level: smaller and suburban single-flat units usually produce larger citizen involvement and interest than large multi-flat-building and centrally located neighbourhoods. 
City politicians, when asked about the prospects of more radical intra-city decentralization, often argue that increasing the scope of functions and the powers of sub-municipal councils would be a mistake if it did not attract significant interest of the local communities. Therefore, it is not entirely clear if neighbourhood activists actually represent local citizens. Embarrassingly low voter turn-out in submunicipal elections provides support for this scepticism. The point is that the low level of interest is often justified by the fact that neighbourhood councils may have only a very limited impact on the every-day lives of citizens. Following the logic of Dahl and Tufte (1973), why pay attention to the election and decisions of councils which are not only more or less powerless, but also do not have any real impact on city politics?

There is negative feedback between limited intra-city decentralization and the disengagement of citizens. The question is whether it is possible to break this vicious circle. The positive relationship that has been discovered between citizens' interest in neighbourhood councils and the scope of spending authorities allocated to those neighbourhood councils provides a foundation for careful optimism.

Mindful of the critical assessment of intra-city decentralization in other countries (as referred to in the introductory section), one may ask whether the idea of sub-municipal governments is not a beautiful, but a utopian concept. Using "city language," are sub-municipal governments a dead-end street for the improvement of city governments? There are arguments supporting the dead-end-street metaphor, but is perhaps such a pessimistic conclusion premature? In fact, in none of the cities, neither in Poland nor in other European countries, has the option of radical decentralization to sub-municipal levels really been tested so far. Bäck et al. (2005) as well as Ringeling et al. (2012) suggest in their studies that city governments are usually not ready to agree to real intra-city decentralization, which would be sufficient to arouse citizens' interest. In Poland, the only (however unsuccessful) attempt to go in that direction was the reform proposal suggested by the mayor of Poznan (which was rejected by the city council).

It may seem that the experiments in Scandinavian cities, in which district councils were often responsible for close to half of the city spending, might be a sufficient test for the concept of decentralization. However, one needs to remember that in most Scandinavian cities there were no districts with councils which would be elected by local citizens, so their direct democratic legitimacy, as well as local roots, were relatively weak. Perhaps instead of a dead-end street we should talk about a vicious circle (or to follow the urban metaphor - vicious roundabout) of marginalization? Citizens are not interested in local councils because such councils are powerless and do not have an impact on their every-day life. Suggestions to assign more power to councils are rejected on the grounds of their weak roots in local communities. The review of the academic literature suggests that it is hard to find an example of the city which has ever tested what would happen if we drove out 
of that vicious roundabout. Would we be on a dead-end street or on the way to better urban governance?

\section{References}

Bačlija, Irena and Miro Haček. 2009. "Political Perception of Urban Sub-Local Entities: A Comparison of Studies from Ljubljana and Swedish Cities.” Khamasin, Jorunal of American University in Cairo 3, 34-47.

Bäck, Henry, Gunnar Gjelstrup, Marit Helgessen, Folke Johansson and Jan Erling Klausen. 2005. Urban Political Decentralization: Six Scandinavian Cities. Wiesbaden: Verlag für Sozialwissenschaften.

Bäck, Henry, Folke Johansson and Helge Larsen. 2000. "Local Government in Nordic Big Cities". In Oskar Gabriel, Vincent Hoffmann-Martinot and Hank Savitch (eds). Urban Democracy. Opladen: Leske + Budrich, 31-72.

Bennett, Robert J. 1997. “Administrative Systems and Economic Spaces.” Regional Studies 31(3), 323-336.

Bennett, Robert J. 1980. The Geography of Public Finance. London/New York: Methuen.

Berry, Jefrey, Portney, Kent, Thomson, Ken. 1995. The Re-birth of Urban Democracy. Washington: Brookings Instiution.

Blakeley, Georgina. 2010. "Governing Ourselves: Citizen Participation and Governance in Barcelona and Manchester." International Journal of Urban and Regional Research 34(1), 130-145.

Bours, Adriann. 1993. "Management, Tiers, Size and Amalgamations of Local Government.” In Robert J. Bennett (ed.). Local Government in the New Europe. London-New York: Belhaven Press.

Burns, Danny, Robin Hambleton and Paul Hoggett. 1984. The Politics of Decentralization: Revitalising Local Democracy. London: Macmillan.

Daemen, Harry and Linze Schaap. 2012. "Puzzles of Local Democracy". In Linze Schaap and Harry Daemen (eds). Renewal in European Local Democracies. Wiesbaden: Springer, 9-26.

Dahl, Robert and Edward R. Tufte. 1973. Size and Democracy. Redwood City: Stanford University Press.

Denters, Bas. 2002. "Size and Political Trust: Evidence from Denmark, the Netherlands, Norway and United Kingdom." Government \& Policy C: Environment and Planning 20(6), 793-812.

Denters, Bas and Pieter-Jan Klok. 2013. Wijk-en dorpsraden in Europa. Enschede: unpublished manuscript. 
Denters, Bas and Pieter-Jan Klok. 2005. “The Netherlands: In Search of Responsiveness". In Bas Denters and Lawrence Rose (eds). Comparing Local Governance: Trends and Developments. London: Palgrave, 65-82.

Derek, Marta and Adam Mielczarek. 2008. "Polish sołectwo: A Latent Field for Rural Governance." In Gabor Peteri (ed.). Mind your own Business: Community Governance in Rural Municipalities. Budapest: LGI/Open Society Institute, 79-130.

Franke, Thomas and Rolf_Peter Löhr. 2001. Neighbourhood Management: A Key Instrument in Integrative Urban District Development. Berlin: Deutsches Institut für Urbanistik.

Griggs, Steven and Mark Roberts. 2012. "From Neighbourhood Governance to Neighbourhood Management: A Roll-Out Neo-Liberal Design for Devolved Governance in the United Kingdom?" Local Government Studies 38(2), $183-210$

Hambleton, Robin and Paul Hogget. 1990. Beyond Excellence: Quality Local Government in the 1990s. Working Paper 85. Bristol: School for Advanced Urban Studies, University of Bristol.

Houlberg, Kurt. 2010. "Municipal Size, Economy and Democracy." In Paweł Swianiewicz (ed.). Territorial Consolidation Reforms in Europe. Budapest: LGI/Open Society Institute, 309-332.

Keating, Michael. 1995. "Size, Efficiency and Democracy: Consolidation, Fragmentation and Public Choice." In David Judge, Gerry Stoker and Harold Wolman (eds). Theories of Urban Politics. London/Thousand Oaks/New Delhi: Sage, $117-134$

Lipset, Seymour M. 1981. Political Man: The Social Bases of Politics. Baltimore: The John Hopkins University Press.

Lowndes, Vivien and Helen Sullivan. 2008. "How Low Can you Go? Rationales and Challenges for Neighbourhood Governance." Public Administration 86(1), $53-74$.

Matczak, Piotr. 2008. Rady osiedli: w poszukiwaniu sensu lokalnego działania. Poznań: Wydawnictwo Naukowe UAM.

Matyjaszczyk, Beata. 2011. Jednostki pomocnicze - analiza uregulowań prawnych. Warszawa: Fundacja Pracownia Badań i Innowacji Społecznych "Stocznia".

Page, Edward and Michael Goldsmith. 1987. Central and Local Government Relations. London: Sage.

Peteri, Gabor. 2008. Mind your own Business: Community Governance in Rural Municipalities. Budapest: LGI/Open Society Institute. 
Piechota, Grażyna. 2013. "Jednostki pomocnicze w strukturach zarządzania polską gminą (analiza funkcjonowania jednostek pomocniczych w śląskich miastach na prawach powiatu." Samorzad Terytorialny 1, 21-35.

Putnam, Robert, Roberto Leonardi and Floriana Nanetti. 1993. Making Democracy Work. Princeton: Princeton University Press.

Quinn, Brid. 2012. “A New Position for Civil Society and Citizens?” In Linze Schaap and Harry Daemen (eds). Renewal in European Local Democracies. Wiesbaden: Springer, 99-118.

Ringeling, Arthur, Harry Daemen and Linze Schaap. 2012. “The Dynamics of Democratic Learning." In Linze Schaap and Harry Daemen (eds). Renewal in European Local Democracies. Wiesbaden: Springer, 191-204.

Rose, Lawrence. 2002. "Municipal Size and Local Non-Electoral Participation: Findings form Denmark, the Netherlands and Norway." Government \& Policy C: Environment and Planning 20(6), 829-851.

"Rozmowa z Prof. Orkiszem, Przewodniczącym Krajowej Konferencji Komitetów Obywatelskich.” 2006. Kurier Zwierzyniecki 3(136), p. 4.

Swianiewicz, Paweł. 2010a. "Czy rozmiar ma znaczenie? Zróżnicowanie opinii mieszkańców o funkcjonowaniu samorządów lokalnych w zależności od wielkości gminy.” Samorząd Terytorialny 4, 5-16.

Swianiewicz, Paweł. 2010b. "If Territorial Fragmentation is a Problem, is Amalgamation a Solution? East European Perspective." Local Government Studies 36(2), 183-203.

Swianiewicz, Paweł and Mikołaj Herbst. 2002. "Economies and Dis-Economies of Scale." In Paweł Swianiewicz (ed.). Consolidation or Fragmentation? The Size of Local Government in Central and Eastern Europe. Budapest: LGI/Open Society Institute, 219-292.

Swianiewicz, Paweł, Joanna Krukowska, Marta Lackowska and Anna Kurniewicz. 2013. Błędne rondo marginalizacji? Jednostki pomocznicze w zarządzaniu wielkimi miastami w Polsce. Warszawa: Elipsa.

Van Asche, Danny, Guido Dierickx. 2007. “The Decentralization of City Governments and the Restoration of Political Trust." Local Government Studies $33(1), 25-47$.

Van Ostaaijen, Julien, Alberto Gianoli and Andrew Coulson. 2012. "The Added Value of Intra-Municipal Decentralization: Comapring Bologna, Rotterdam and Birmingham." In Linze Schaap and Harry Daemen (eds). Renewal in European Local Democracies. Wiesbaden: Springer, 145-164. 